INTERNATIONAL JOURNAL OF

MULTIDISCIPLINARY STUDIES IN ARCHITECTURE

AND CULTURAL HERITAGE

\title{
The National Museum of Egyptian Civilization and its Temporary Exhibition in
}

2017

Mahrous Elsanadidy a, $b$, *

a Ph.D. Candidate in the Heritage and Museum Studies, Helwan University.

b Chief Curator in the National Museum of Egyptian Civilization.

\begin{abstract}
The aim of this exhibition was to shed light on some of the bright aspects of the great civilization of Egypt, which has offered various inventions and creativity for making the human civilization from ancient times to the present time. Therefore, the exhibition tries to send messages about the Egyptian character through the ages to show the continuous pioneering role of the Egyptian civilization through the ages. In order to Provide our the public with historical, technical information and studies on these crafts, we have used an interactive framework addressing all ages, abilities and different intellectual levels in a simple and interesting presentation such as panel, labels, banners, films, and mobile applications.

Keywords

National Museum.

Egyptian Civilization.

Temporary Exhibition.

United Nations Organization.

UNESCO.
\end{abstract}

\section{Introduction}

The National Museum of Egyptian Civilization is one of the largest cultural projects currently being constructed by the Egypt's Ministry of Antiquities, in technical partnership with the UNESCO of the United Nations organization. The purposes of its establishment are to be a cultural, educational, and scientific and research center, and global community communication center (The National Museum of Egyptian Civilization n.d.). As well as, a museum will be a center for preserving the Egyptian cultural heritage and protecting it from looting and extinction. This heritage contains what is material and what is immaterial: materialheritage is tangible heritage, which is all things produced and created by the Egyptian man throughout the ages in science, arts, literature, architecture, engineering, astronomy, language, administration, beliefs and religions. Regarding immaterial heritage is intangible heritage or oral heritage like customs, traditions, proverbs, folk tales, and literal 
INTERNATIONAL JOURNAL OF

MULTIDISCIPLINARY STUDIES IN ARCHITECTURE

AND CULTURAL HERITAGE

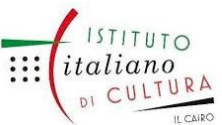

skills inherited from grandparents from the distant or near past. As for the museum's vision, it works to revive the Egyptian identity, especially its positive characters such as strong determination, patience andhard work through displaying the Egyptian contributions and achievements in human being civilization through the various ages; from prehistoric times and the dawn of civilization to thepresent time via GrecoRoman, Islamic, modern times, and current age. The main missions ofthe museum is collecting and acquiring antiquities and traditional artifacts from all sites on Egyptian land. Those artifacts are selected according to a certain policy which will serve museum proposes; exhibition, education, and preservation (The National Museum of Egyptian Civilization 2007, 10-11). Regarding both of artifacts are chosen to be displayed in permanentor temporary spaces. The Scientific Committee of the museum exhibition set certain themes for museum exhibitions e.g. the dawn of civilization, the Nile River, writing and science, Mummies and embalming )455 444 1991 the state and society, material culture, andbeliefs and thinking (The National Museum of Egyptian Civilization 2007, 8-9). As well as atemporary exhibition hall in which changeable exhibitions take place according to the museum's plan and strategy. In addition to, one of the missions of the museum is also to restore and conserve the collections that will be displayed or not displayed through its conservation labs (The National Museum of Egyptian Civilization 2007, 15). The National Museum of Egyptian Civilization is as well as established by modern storerooms for preserving objects according to its type of material and its size. The type of material is either organic or inorganic: organic artifacts made of such materials: wood, textile, leather, ivory, bone, plants fibers, manuscripts, oil paintings, etc ... Inorganic materials are made of stone materials such as granite, limestone, basalt, basalt, marble, marble ... and Such as clay, pottery, porcelain, glass,metal (The National Museum of Egyptian Civilization 2007, 17).

The Museum of Civilization is a promising scientific center for the conservation, restoration and study of archeology because It contains many 
INTERNATIONAL JOURNAL OF

MULTIDISCIPLINARY STUDIES IN ARCHITECTURE

AND CULTURAL HERITAGE

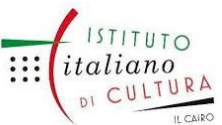

specialized laboratories in the restoration of organic and inorganic compounds, through specialists in each material. There is also a center for research and conservation of monuments, established with modern equipmentand devices for researching in various disciplines such as plants, Animals, ancient anthropology, geology, chemistry, biochemistry, physics, DND and microbiology. There is also a quarantine for the conservation and maintenance of mummies, whether human, birds oranimal mummies (The National Museum of Egyptian Civilization 2007, 16).

From the missions of the Museum of Civilization is also a center for exchanging scientific researches between Egyptian and non-Egyptian researchers on archaeology, history, museology, applied sciences and art through holding many conferences, seminars, forums and training workshops. In addition, the museum carries out other educational activities through the Department of Museum Education and Community Communication where it holds workshops and training courses for the community surrounding the museum whether local or global. The museum also offers fun and entertainment through holding concerts in its large theater or open theater. And those wishing to meditate and go back to the past can come and see Cairo landmarks of Muqattam Mountain and the citadel of Salah alDin and Islamic mausoleums in the area of Imam Shafi'i, as well as to enjoy the wide area surrounding the museum where The museum overlooks a Lake of Ein el-Sira with its natural water that flows from the depths of the earth called the Eye of Life. As well as, Visitors can enjoy the green surface of the Al-Fustat Park, which is just to north of the museum (The National Museum of Egyptian Civilization 2007, 5).

As for the beginning of the idea of establishing the museum of civilization, it dates backto 1939 under the reign of King Farouk. In fact, the museum was established in العشماوى 1949

)285-279 2512 in the area of the fair land or Aljazeera - the current opera house but this museum did not achieved the purposes targeted in displaying the Egyptian civilization becauseit displayed the Egyptian civilization through using dioramas to 
INTERNATIONAL JOURNAL OF

MULTIDISCIPLINARY STUDIES IN ARCHITECTURE

AND CULTURAL HERITAGE

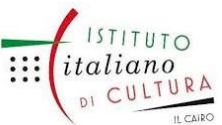

ISSN: $2735-4415$

VOLUME 3, ISSUE1, 2020, 120-134.

www.egyptfuture.org/ojs/

represent Egyptian civilizationscenes by modern art.

Then, with the completion of the Nubia's monuments Rescue Project implemented jointly with UNESCO at the end of the seventies of the twentieth century, the Egyptian government decided to continue cooperation with UNESCO in the implementation of buildingtwo museums: the Museum of Civilization in Cairo and the Nubian Museum in Aswan (The National Museum of Egyptian Civilization 2007, 3).

Then, after several meetings between two parties, it was announced a design competition among Egyptian architects in 1983. In 1984, The design project of Dr. El-Ghazali Kassiba (The National Museum of Egyptian Civilization 2007, 3), Professor of Architecture atthe Faculty of Fine Arts of a Helwan University, was the winner of the best design. The area of the fair land "Land of Exhibitions" or Aljazeera was initially designated for building the museum project, but after the State of Japan provided a grant to rebuild the Egyptian Opera House, which was burned down in 1971, the museum land was withdrawn for the construction of the Opera House, and then the project was frozen until the end of the 20th century till Choosing the location of the land of Al-Fustat in 1998 (The National Museum of Egyptian Civilization 2007, 3).

It is a worth noting that the new site of the National Museum of Egyptian Civilization in the area of Al-Fustat - the first capital of Islamic Egypt - is truly a genius site to build this museum. This site is characterized by its being located in an ancient cultural area and rooted in the depth of Egyptian history, because it is surrounded by many cultural centers of different ages in Egypt. To the south of it there are sites of civilizations of prehistoric times: the civilizations of Maadi, Helwan, Jerzah and Atfih, to the far west of it, we can see from the glasspyramid hall which is above the core exhibition gallery all the landmarks of greater Cairo suchas the Giza and Saqqara pyramids, near of it a fortress of the oldest military fortresses in Egypt: One of the most important fortresses in the Persian and Greek Roman period, which 
INTERNATIONAL JOURNAL OF

MULTIDISCIPLINARY STUDIES IN ARCHITECTURE

AND CULTURAL HERITAGE

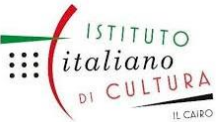

was builton top of the Hanging Church that is one of the most important and the oldest Christian monuments in Egypt. Also we can see near of the museum one of the oldest mosques in Egyptthat was built by Amr ibn al-Aas, and the ruins of the ancient city of Al-Fustat. To the north ofthe museum are many Islamic and historical landmarks of Cairo, such as the citadel of Salah al-Din al-Ayyubi and the archaeological mausoleums in the Imam al-Shafei area, including theImam al-Shafi'i mausoleum, and the tombs of Muhammad Ali's family.

Al-Fustat was also distinguished as one of the most famous centers of traditional crafts.A pottery craft is undoubtedly the most important and oldest crafts, which is still practiced from prehistoric times to the present time. Moreover, in the past, Al-Fustat was an important center of the Egyptian textile industry, especially in the Islamic era, because we found in the excavations at the site of the Museum before building museum constructions a dying house dates to the Fatimid era (9691171 A.D). The area of Al-Al-Fustat is known to the present daywith another craft no less important than the previous one, namely leather tanning, which is only a few hundred meters from the museum.

Therefore, the site was distinguished by its previous features. So, when it was decided the temporary exhibition hall was prepared as a partial opening of the Museum of Civilization.The museum has got started by choosing a theme about the Egyptian crafts through the ages linking the museum by its surrounding site and Egypt as well. Thus, the selection of nearly four hundred and fifty pieces of antiquities and heritage from different areas of Egypt. Some of them came from the Egyptian Museum, Islamic Museum, Coptic Museum, historic Cairo, Luxor and Aswan. These pieces that reflect different periods of the prehistoric cultures of Badari culture in Assiut, of Naqada I,II, and III cultures in Qena, of Fyoum culture and of Maadi culture ( Wodzińska 2009) (Wodzińska 2009, 25-147). The others date back pharaonic,Greek, Roman, Islamic, modern and even contemporary times. 


\section{The new Exhibition:}

One of the museum's missions is to establish exhibitions, So, We opened the temporary exhibition "' the Egyptian crafts through the ages"' in February 2017. The sizeof this gallery is about one thousand meter square. Through this exhibition, we try to tell ourvisitors the story of the Egyptian crafts through the ages saying that the Egyptian has known many crafts through the ages such as hunting, agriculture, pottery, textiles, woodworking, jewelry, metalworking, glass working.... But, we focus on these four crafts: the pottery, textiles, woodworking, and jewelry (the temporary exhibition "' the Egyptian crafts through the ages" 2017).

\section{Exhibition story:}

In order to express about aforementioned themes, we have used real antiquities traditional, replica objects as follows:

The first theme is the pottery craft ( لوكاس1991, 596-623):

We display a distinguished collection of pottery of prehistoric periods of the Badari culture which found in the Badari area in Assyout governorate, of the black topped pottery ofNaqada I culture, decorated pottery of Naqada II and III cultures. As well as, we display objectsrelating pharaonic, Greco-Roman, Islamic, modern and even contemporary times. Among thefine art masterpieces, we display a pottery maker statue of limestone that is one of the masterpieces of the old kingdom era of the pharaonic periods to represent one technique used in making pottery items. There is no doubt that this craft is still famous in many areas across Egypt so far in Siwa, sharqqya governorate and Fayoum So we display many objects related to traditional craft in those places 
INTERNATIONAL JOURNAL OF

MULTIDISCIPLINARY STUDIES IN ARCHITECTURE

AND CULTURAL HERITAGE

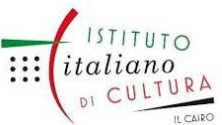

ISSN: $2735-4415$

VOLUME 3, ISSUE1, 2020, 120-134.

www.egyptfuture.org/ojs/

The Second theme: the textile Craft (لوكاس1991, 224-257):

The museum presents the story of the textile Craft because of the great fame that Egyptenjoys from ancient times till modern times, especially the linen fabric, which used to be planted in the Delta to now. The Egyptian did not let us guess how the steps of the textile industry were because they documented that on the reliefs of their tombs walls and from objectswe found as a model of a textile workshop in the tomb of the chief craftsmen Maket - Re, foundat the Alasasif area in the West Bank of Luxor. This tomb is from the Middle Kingdom of Pharaonic period. in addition to many textiles that were discovered in archaeological sites, including those used as coffins. The most important of which is tissues related to the reign of King Tuthmosis III, the sixth king of the Eighteenth Dynasty. In addition we present some ofthe statues that document fashion in different eras from the Old Kingdom, Middle Kingdom and New Kingdom of the Pharaonic times. As well as robes represent the Egyptian Christian and Islamic religious identity.

The third Craft: woodworking craft ( لوكاس 1991, 692- 735):

The craft of woodworking (Killen 1994, 7-50) is one of the most ancient Egyptian craftswhich recorded its scenes on many tombs of the Old Kingdom at Saqqara, of the Middle Kingdom at Beni Hassan, of the New Kingdom at Thebes. Regarding the objects displayed include a funerary panel, chair of Queen HetepHeres, mother of the king of Khufu who is theowner of the Great Pyramid in Giza, the military chariot of the King Tuthmosis IV which commemorates one of the battles fought in Syria. As we displayed set of chairs of Sennedjem, of Yoya and toya, wooden doors and the pulpit of Abu Bakr Mezher of the era of the Mamluk.In addition, we display some a balcony wooden element called Mashrafyaih and two Pope's chairs, traditional woodworking, which was made in the system called joint art or well knownas Arabesque . 


\section{The Fourth theme: jewelry Craft}

The jewelry Craft is one of the oldest crafts known in Egypt from prehistoric times( لوكاس 1991, 368-372). It is characterized by simplicity, beauty and symbolism. This industryreached its peak during the Pharaonic times, especially in the Middle Kingdom and the New Kingdom. For the most important items we display a golden crown to princess and a belt of prince Ptah-shepses from the Old Kingdom, The golden pendants of the king Amenemhat III and his family from the middle Kingdom age, a golden earrings engraved with the titles of King Seti I and the bracelets of the King Ramses II. As well as, there are the necklaces of King Semnakh- kare, the successor of King Akhenaten and some of the rings and amulets. Asfor the silver artifacts, we display objects from different eras. To express different customs and traditions for wearing jewelry everywhere in Egypt, we conclude the exhibition gallery with types of accessories and ornaments which women are in the oasis of Siwa in western Deseret,the Nubia south of Egypt, Upper and Lower Egypt.

Finally, the aim of this exhibition was to shed light on some of the bright aspects of thegreat civilization of Egypt, which has offered various inventions and creativity for making thehuman civilization from ancient times to the present time. Therefore, the exhibition tries to send messages about the Egyptian character through the ages to show the continuous pioneering role of the Egyptian civilization through the ages. In order to Provide our the publicwith historical, technical information and studies on these crafts, we have used an interactive framework addressing all ages, abilities and different intellectual levels in a simple and interesting presentation such as panel, labels, banners, films, and mobile applications. As wellas, the exhibition also aims to: Preserve Egypt's tangible and intangible heritage related to suchof the crafts of pottery, textiles, jewelry and woodworking throughout the ages; Highlight the leading role of Egypt in the crafts of pottery, textile, jewelry and woodworking 
through the ages; Work to raise awareness of Egyptian civilization and heritage to spread the spirit of loyalty, patriotism and pride in the homeland; Work to promote the spirit of loyalty and belonging between the museum and the surrounding environment; Highlight the community role of the museum and its interaction with the surrounding environment in order to revive these traditional crafts and preserve them from extinction; Interact with the community and itscontemporary problems and issues awareness and participate in solving them for the development of society; Present a high-quality display that promotes manners, morals and general taste.

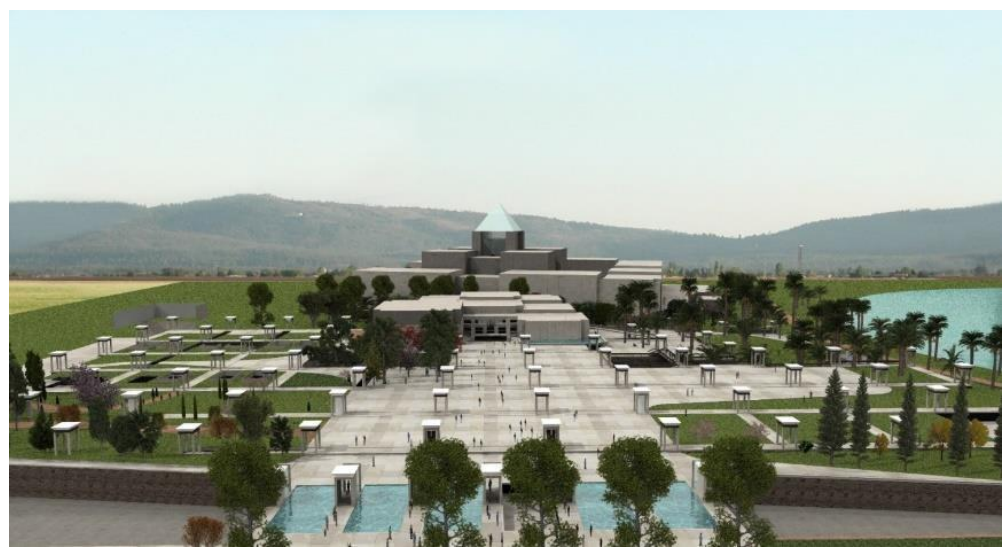

Fig. 1 - Overview of the National Museum of Egyptian Civilization. 


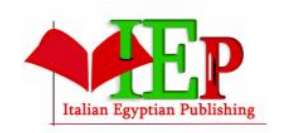

ISSN: $2735-4415$

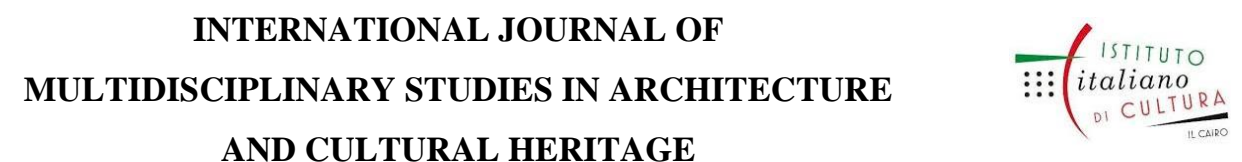
AND CULTURAL HERITAGE

VOLUME 3, ISSUE1, 2020, 120-134.

www.egyptfuture.org/ojs/

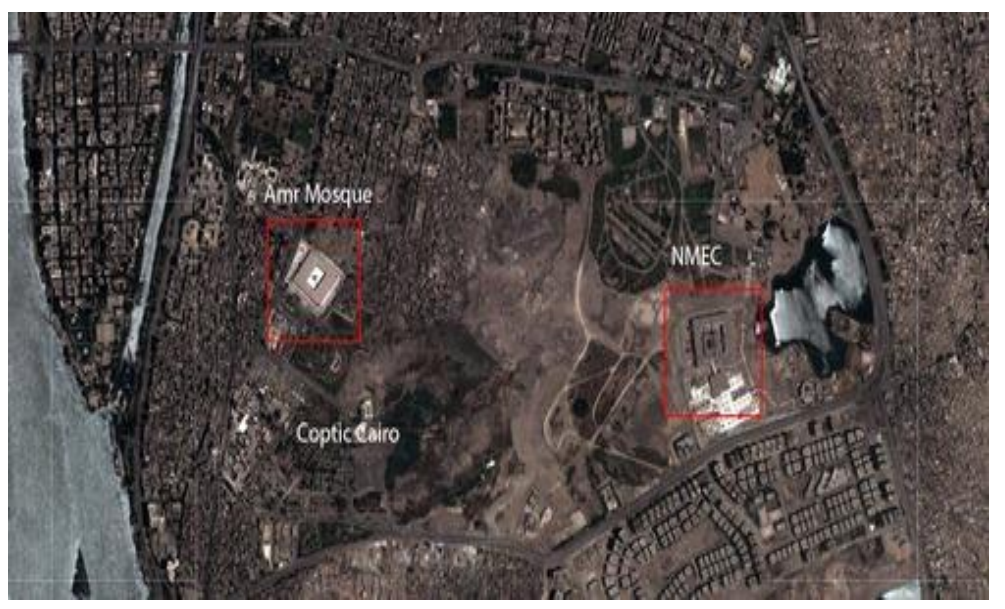

Fig. 2 - Alfustat Area Including the National Museum of Egyptian Civilization Site.

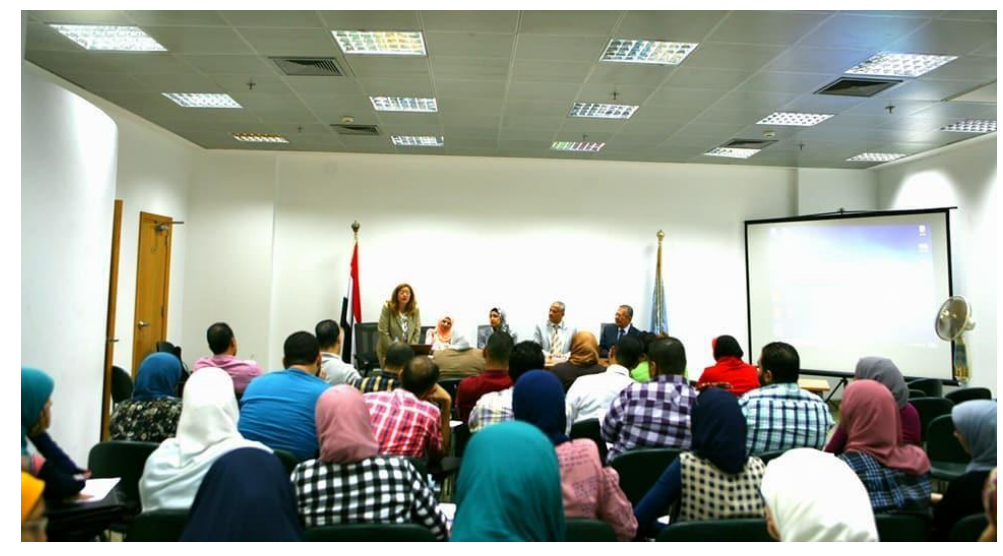

Fig. 3 - Training Under UNESCO.

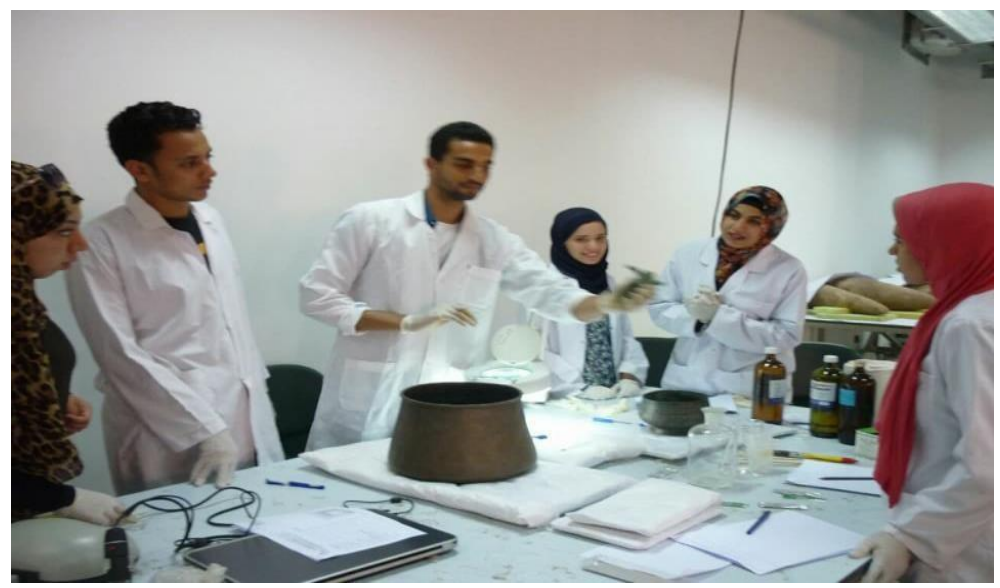


INTERNATIONAL JOURNAL OF

MULTIDISCIPLINARY STUDIES IN ARCHITECTURE AND CULTURAL HERITAGE

Fig. 4 - Training Under NMEC Conservators.

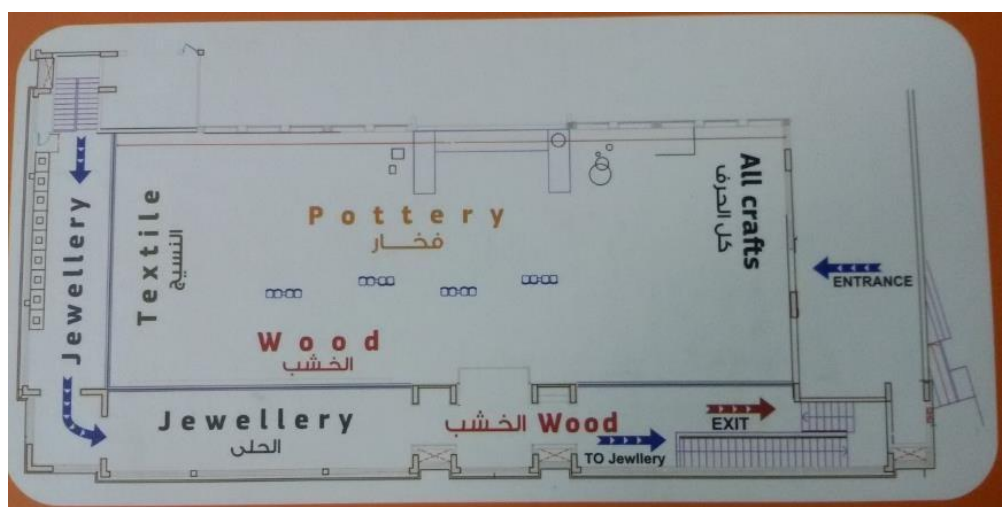

Fig. 5 - Plan of the Temporary Gallery on the Egyptian Crafts.

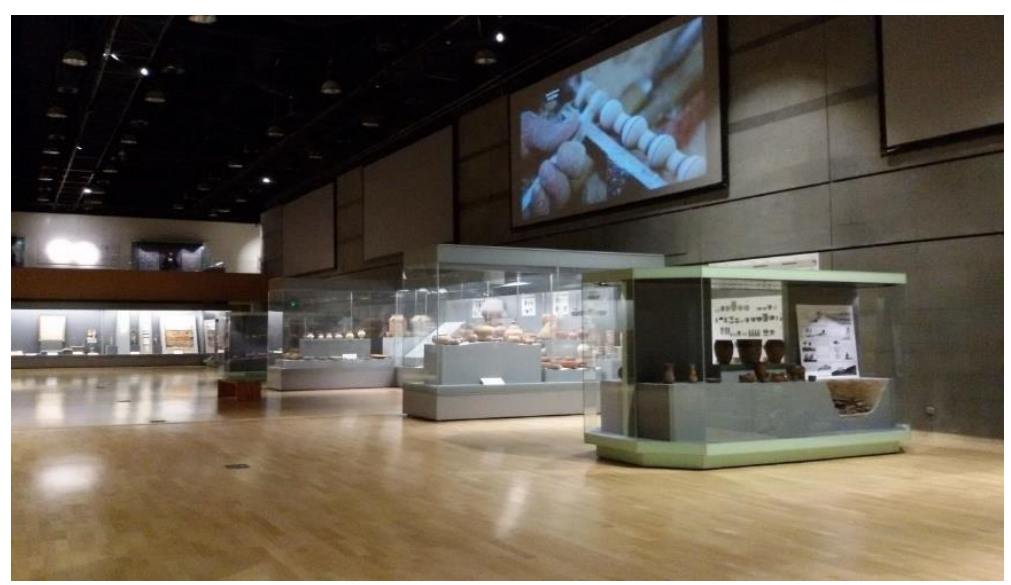

Fig. 6 - Pottery Displays in the Temporary Gallery on the Egyptian Crafts. 
INTERNATIONAL JOURNAL OF

MULTIDISCIPLINARY STUDIES IN ARCHITECTURE AND CULTURAL HERITAGE

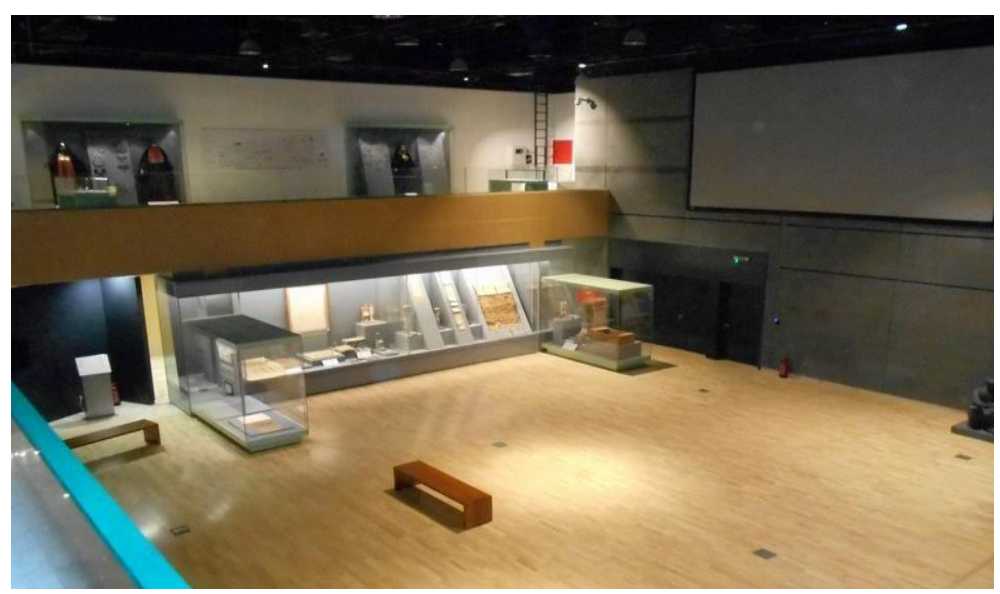

Fig. 7 - Textiles Displays in the Temporary Gallery on the Egyptian Crafts.

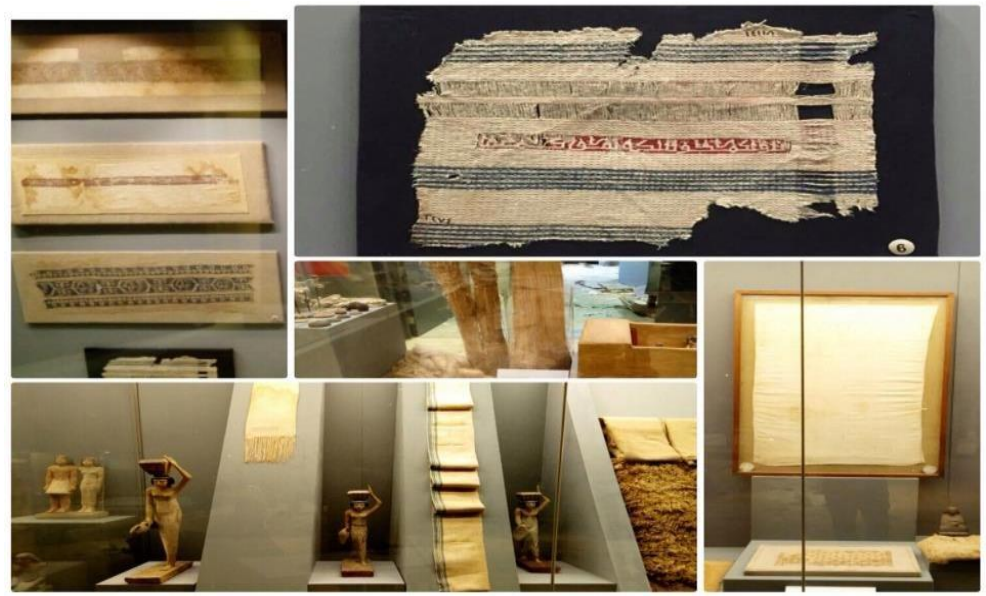

Fig. 8 - Textiles Items Displayed in the Temporary Gallery on the Egyptian Crafts.

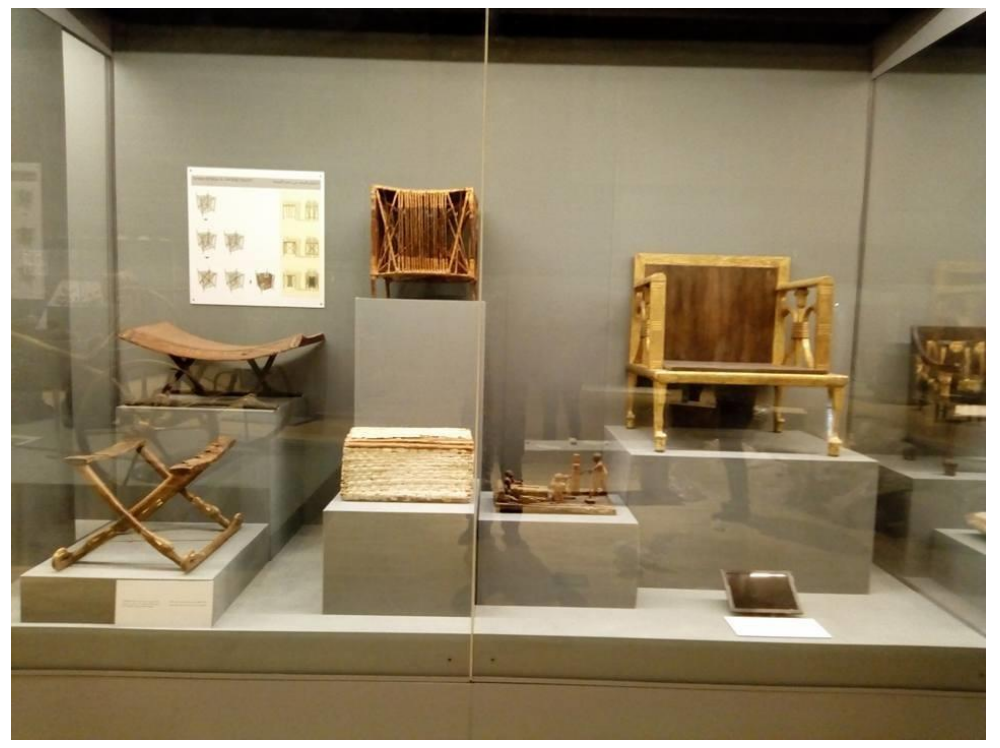


INTERNATIONAL JOURNAL OF

MULTIDISCIPLINARY STUDIES IN ARCHITECTURE

\section{AND CULTURAL HERITAGE}

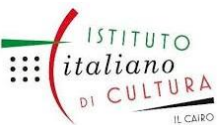

Fig. 9 - Woodworking Objects Displayed in the Temporary Gallery on the Egyptian Crafts.

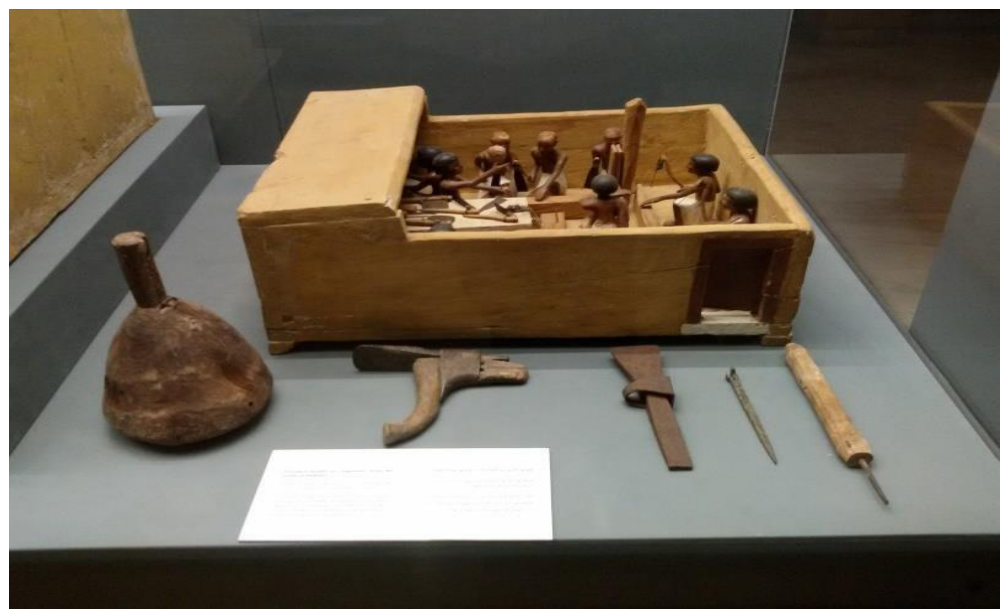

Fig. 10 - Carpentry Tools and a Model of Carpentry Workshop Displayed in the Temporary Gallery onthe Egyptian Crafts.

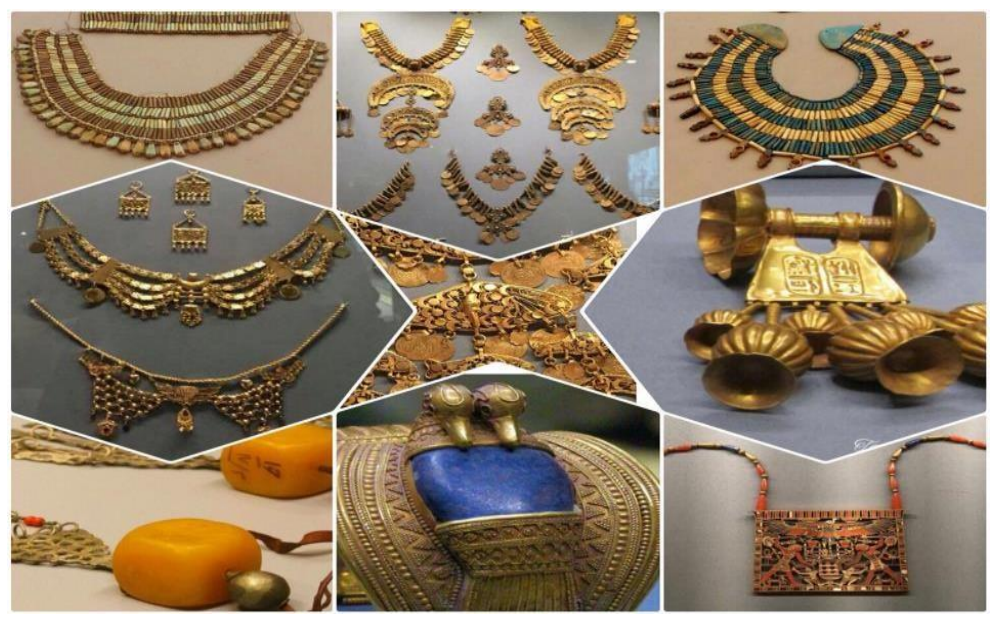


INTERNATIONAL JOURNAL OF

MULTIDISCIPLINARY STUDIES IN ARCHITECTURE

\section{AND CULTURAL HERITAGE}

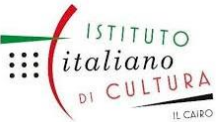

Fig. 11 - Golden Objects Displayed in the Temporary Gallery on the Egyptian Crafts.

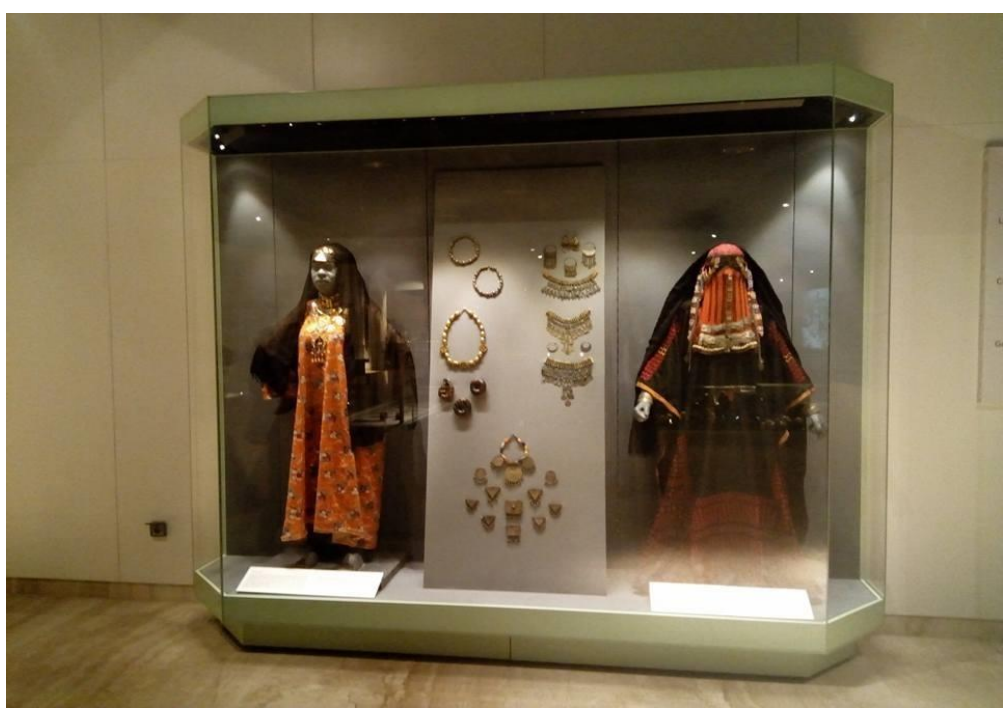

Fig. 12 - Traditional Jewelry of Nubia and Sinai Women Displayed in the Temporary Gallery on theEgyptian Crafts.

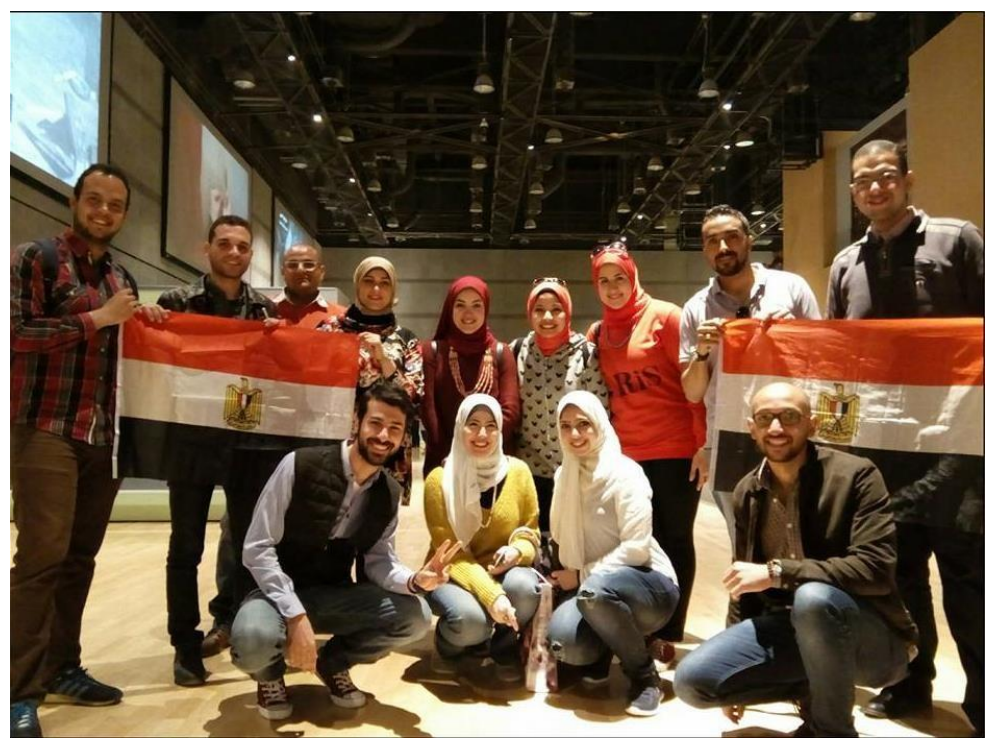

Fig. 13 - Visitors of the Temporary Gallery on the Egyptian Crafts Raising Egyptian Flags. 
INTERNATIONAL JOURNAL OF

MULTIDISCIPLINARY STUDIES IN ARCHITECTURE

AND CULTURAL HERITAGE

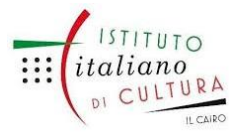

ISSN: $2735-4415$

VOLUME 3, ISSUE1, 2020, 120-134.

www.egyptfuture.org/ojs/

\section{References:}

Killen, Geoffrey . Egyptian Woodworking and Furniture. British Library Cataloguing in Pub: 'IT

PrintingServices, Press Buildings, 1994.

Wodzińska, Anna. A Manual of Egyptian Pottery: Fayum A-Lower Egyptian Culture. Vol. Volume 1. 4 vols.

Cairo, Egypt: Ancient Egypt Research Associates, Inc., 2009.

"The National Museum of Egyptian Civilization." Cairo: The National Museum of Egyptian Civilization, 2007.

The National Museum of Egyptian Civilization. n.d.

http://www.unesco.org/new/en/culture/themes/museums(accessed August 20, 2018).

"the temporary exhibition " the Egyptian crafts through the ages"." the temporary exhibition " the Egyptiancrafts through the ages". Cairo, 2017.

"UNESCO training report to NMEC Staff ." training of Human resources, Cairo, 2011.

Received: February 15, 2018

Accepted: April 20, 2018 